https://doi.org/10.5800/GT-2017-8-3-0298

\title{
DEPLETED SSZ TYPE MANTLE PERIDOTITES IN PROTEROZOIC EASTERN SAYAN OPHIOLITES IN SIBERIA
}

\author{
Kuo-Lung Wang1, 2, Zhuyin Chu'3, Marina A. Gornova4, Sergei Dril4, \\ Vasilii A. Belyaev1, 4, Kuan-Yu Lin 1, 2, Suzanne Y. O'Reilly5 \\ ${ }^{1}$ Institute of Earth Sciences, Academia Sinica, Taipei, Taiwan \\ ${ }^{2}$ Department of Geosciences, National Taiwan University, Taipei, Taiwan \\ 3 Institute of Geology and Geophysics, Chinese Academy of Sciences, Beijing, China \\ ${ }^{4}$ A.P. Vinogradov Institute of Geochemistry, Siberian Branch of RAS, Irkutsk, Russia \\ ${ }^{5}$ CCFS/GEMOC Key Centre, Department of Earth and Planetary Sciences, Macquarie University, \\ Sydney, Australia
}

For citation: Wang K.-L., Chu Z., Gornova M.A., Dril S., Belyaev V.A., Lin K.-Y., O'Reilly S.Y., 2017. Depleted SSZ type mantle peridotites in Proterozoic Eastern Sayan ophiolites in Siberia. Geodynamics \& Tectonophysics 8 (3), 583-587. doi:10.5800/GT-2017-8-3-0298.

N.L. Dobretsov et al. [1985] first described the rock complexes in Eastern Sayan as ophiolites. Ophiolites formed in Dunzhugur island arc and were obducted onto Gargan block, a Neoarchean crystalline basement of the Tuva-Mongolian Massif (TMM), as a single nappe [Khain et al., 2002; Kuzmichev, 2004]. Zircons from plagiogranite were dated at $1021 \pm 5 \mathrm{Ma}$ by multigrain TIMS and $1020 \pm 1$ Ma by $\mathrm{Pb}-\mathrm{Pb}$ single-grains evaporation method [Khain et al., 2002]. Later [Kuzmichev, Larionov, 2013] analysed 12 grains of detrital zircons from gravelstone of the Dunzhugur formation and obtained $206 \mathrm{~Pb} / 238 \mathrm{U}$ ages from $844 \pm 8$ to $1048 \pm 12 \mathrm{Ma}$. Careful examination of these data shows that ${ }^{206} \mathrm{~Pb} /{ }^{238} \mathrm{U}$ ages for concordant zircons only vary from $962 \pm 11$ to $1048 \pm 12$ Ma. Two groups of data give Concordia ages of $974 \pm 11$ and $1028 \pm 10$ Ma. Rocks of the Dunzhugur complex are characterized by slightly negative to slightly positive $\varepsilon \mathrm{Nd}(\mathrm{t})$ values from -1.0 to +1.5 and Late Palaeoproterozoic depleted mantle $\mathrm{Nd}$ model ages of 1.8-1.6 Ga [Sklyarov et al., 2016]. The Dunzhugur complex was intruded by tonalite plutons of the Sumsunur complex dated at $785 \pm 11 \mathrm{Ma}$ [Kuzmichev et al., 2001] and 811 \pm 7 Ma [Kovach et al., 2012]. These tonalites have strongly negative $\varepsilon N d(t)$ values from -13.2 to -12.3 and $\mathrm{Nd}$ model ages of $2.5-2.4 \mathrm{Ga}$, suggesting formation of these melts from a mixture of 


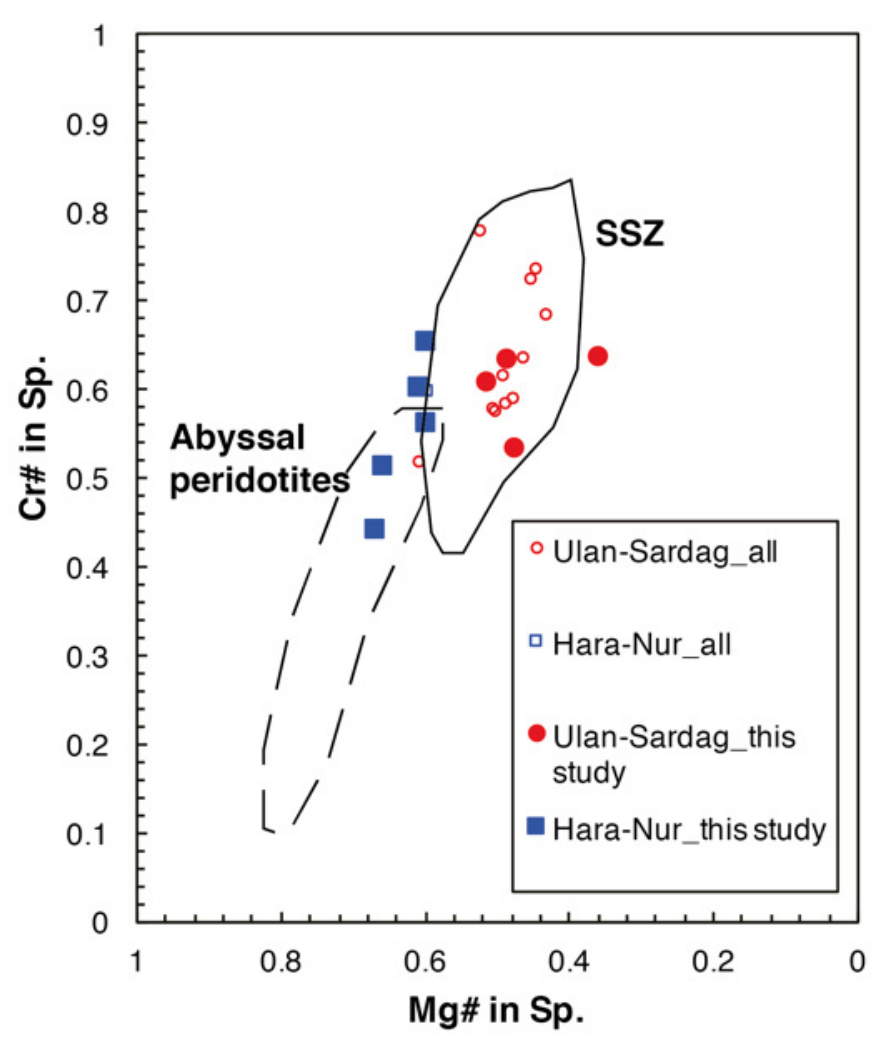

Fig. 1. Diagram of Cr\# vs. Mg\# of spinel (modified from [Dick, Bullen, 1984].

Neoproterozoic juvenile and Archaean crustal sources [Kovach et al., 2012].

The Eastern Sayan ophiolites, also named Dunzhugur ophiolites, are composed of several tectonic units/ massifs include (1) Ospin (Ospin-Kitoy), (2) Ilchir, (3)
Ulan-Sardag, (4) Hara-Nur, and (5) Dunzhugur from east to west (Fig. 1). Authochton rocks are represented by terrigenous-carbonate deposits of Irkut and Ilchir formations, metamorphosed in green schist to epidoteamphibolite-facies. Ophiolitic peridotites from two localities: Ulan-Sardag (US; one dunite, two harzburgites and one orthopyroxenite) and Hara-Nur (HN; five harzburgites) are studied here.

Geochemistry and geodynamic implications. Two harzburgites from Hara-Nur massif did not undergo metamorphism, whereas metaperidotites and serpentinites underwent metamorphism in lower amphibolite facies. Ulan-Sardag massif is composed of metaperidotites, which formed after serpentinites as a result of prograde metamorphism up to mid-amphibolite facies. Composition of both their relic Sp cores is primary and allows to make petrogenetic investigation. On the diagram of Cr\# vs. Mg\# of spinel [Dick, Bullen, 1984; Fig. 1], some HN harzburites locate in abyssal peridotite field, but a few are close to the supra-subduction zone (SSZ) field. All US harzburgites are in the field of SSZ.

Both $\mathrm{HN}$ and US harzburgites have negative correlations between $\mathrm{Cr} \#$ in $\mathrm{Sp}$. and $\mathrm{WR}_{2} \mathrm{Al}_{2} \mathrm{O}_{3}$ and $\mathrm{CaO}$ indicating degrees of partial melting/melt extraction play a main role in controlling their geochemical features (Fig. 2). US orthopyroxenite has the lowest $\mathrm{MgO}$ and $\mathrm{La} / \mathrm{Yb}$ but highest $\mathrm{Al}_{2} \mathrm{O}_{3}$ and $\mathrm{CaO}$. Although US dunite has the lowest $\mathrm{Al}_{2} \mathrm{O}_{3}$, its high $\mathrm{CaO}$ and $\mathrm{La} / \mathrm{Yb}$ suggest that this dunite was readily modified by later metasomatism.

The harzburgites and dunites, resembling subduction zone peridotites, are represented by depletion of MREE with respect to HREE (Fig. 3). In addition, significant enrichments of LILE, LREE and some HFSE are
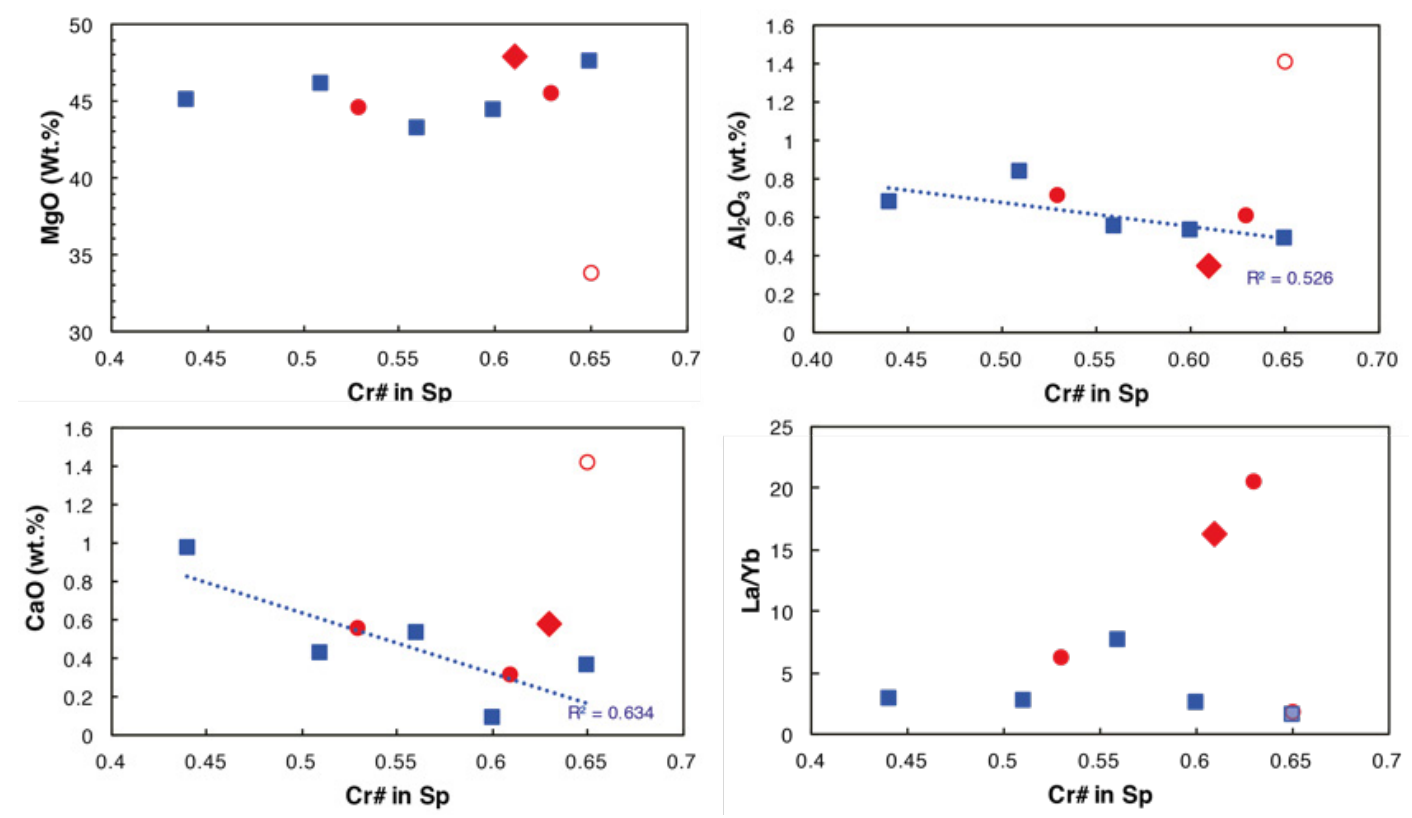

Fig. 2. Diagrams of Cr\# in Sp. vs. WR MgO, WR $\mathrm{Al}_{2} \mathrm{O}_{3}$, WR CaO and WR La/Yb. 


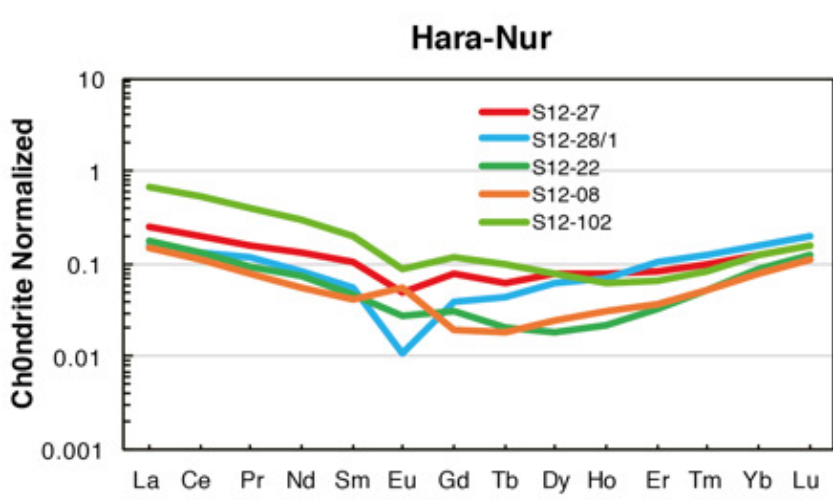

Ulan-Sardag

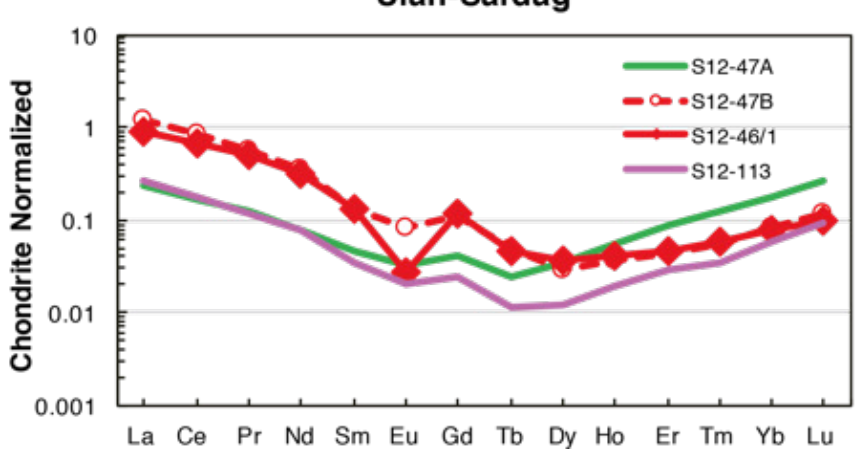

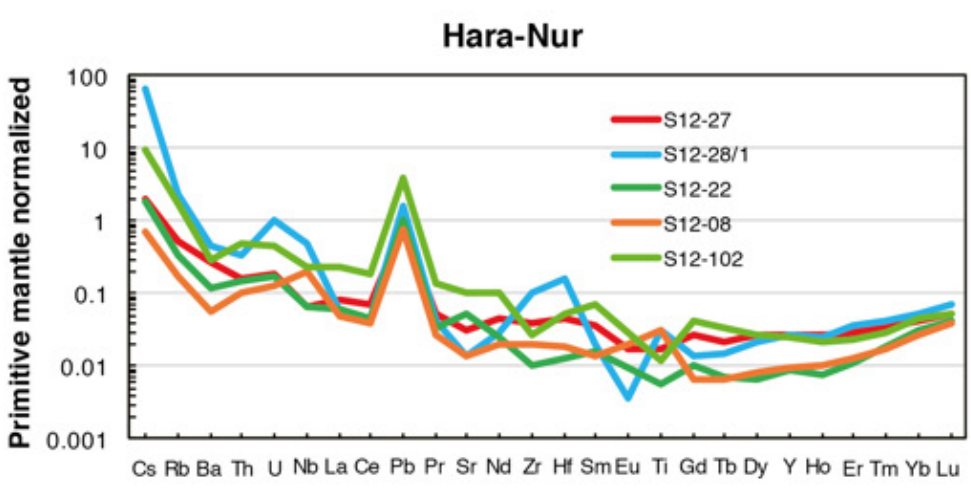

Ulan-Sardag

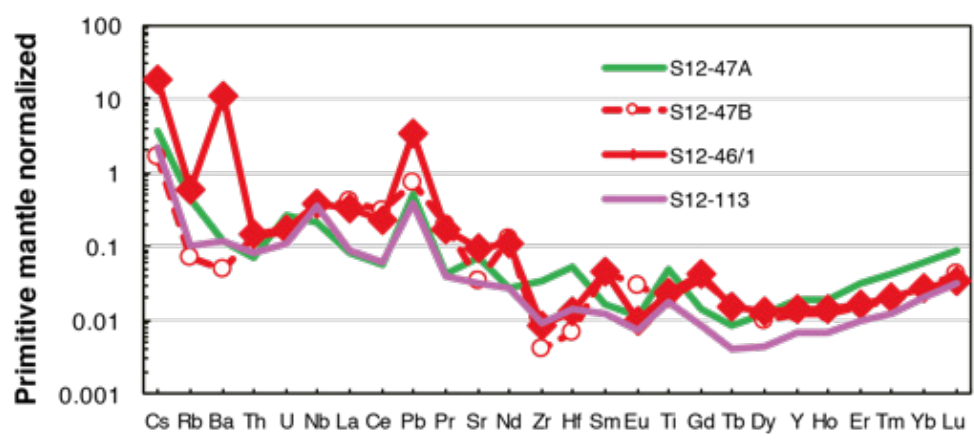

Fig. 3. Chondrite/Primitive mantle-normalized WR trace-element patterns of HN (upper) and US (lower) peridotites.

consistent with a possible interaction of these peridotites with fluids or melts derived from the subducted slab [e.g. Parkinson, Pearce, 1998]. Partial enrichment of LREE and incompatible elements $(\mathrm{Ba}, \mathrm{Nb}$ and $\mathrm{Pb}$ ) is believed to result from the interaction of boninitic magmas with peridotites in a mantle wedge. US harzburgites are characterized by more sharper decrease from HREE to MREE with respect to those of US dunite, orthpyroxenite and HN harzburgites. The unmetamorphosed harzburgites and dunite show pronounced positive Ti anomalies. In addition, all rock types show pronounced peaks in $\mathrm{Nb}$ and $\mathrm{Pb}$.

The HSE abundances exhibit strongly fractionated patterns for both US and HN harzburgites (Fig. 4). US dunite has enrichments in Os, Ir and $\mathrm{Ru}$ and the highest abundance among all. Another US harzburgite (S12-113) also show typical residual pattern. All other harzburgites show the intermidiate patterns between residual and melt indicating they had been experienced interaction with later metasomatic melts/fluid. Such melts/fluid metasomatism also caused fractionation among the HSEs. Among them, Os-Ir (both I-PGE), Pt-Ir and Re-Ir covariation in US dunite/harzburgite, Pd-Ir (P-PGE/I-PGE) co-variation for both US and HN peridotites had been modified (Fig. 5).

Dunite, harzburgite and chromitite showing residual PGE patterns (Pd/Ir=0.07-0.62) with low ${ }^{187} \mathrm{Re} /{ }^{188} \mathrm{Os}$ ratios (0.0037-0.0632) yield tMA model ages of 2.38, $1.84,1.44$ and 1.22 Ga (1870s/1880s=0.11353-0.11978). A low ${ }^{187} \mathrm{Re} /{ }^{188}$ Os harzburgite with IPGE-depleted PGE pattern and one sulfide in dunite yield tMA model ages of 1.38 and 1.53 Ga (Table). The Re-Os isotope compositions of $\mathrm{HN}$ and US peridotites yield model age peaks at $\sim 2.38 \mathrm{Ga}, \sim 1.84 \mathrm{Ga}$ and $\sim 1.44-1.22 \mathrm{Ga}$, which may
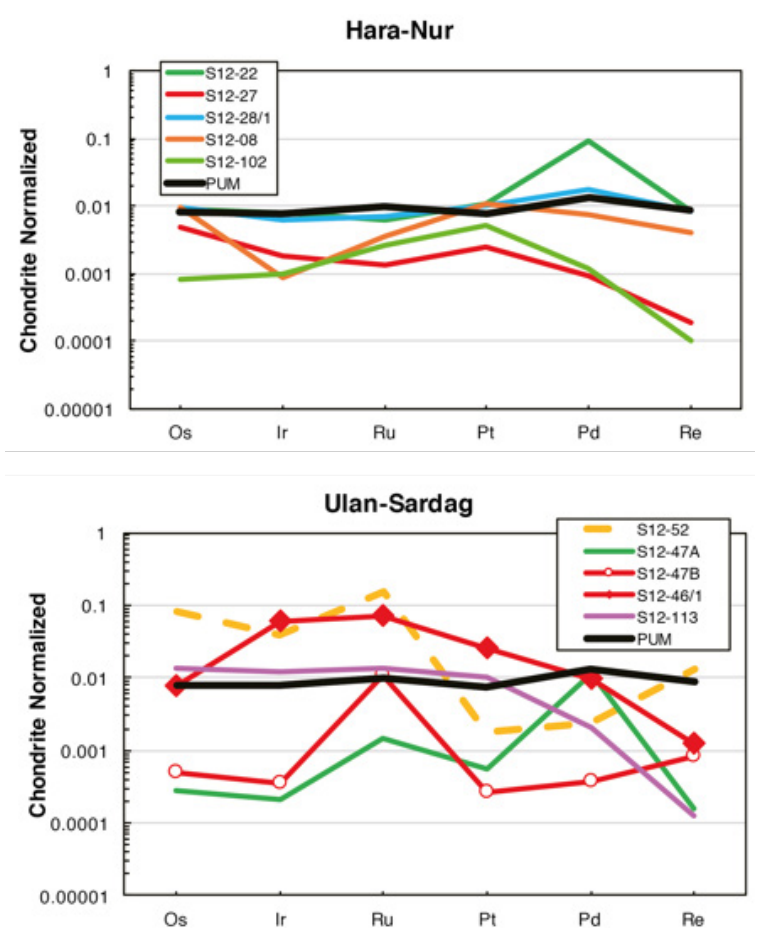

Fig. 4. Chondrite-normalized HSE abundances of US and HN peridotites. Black line shows the composition of primitive mantle after. 


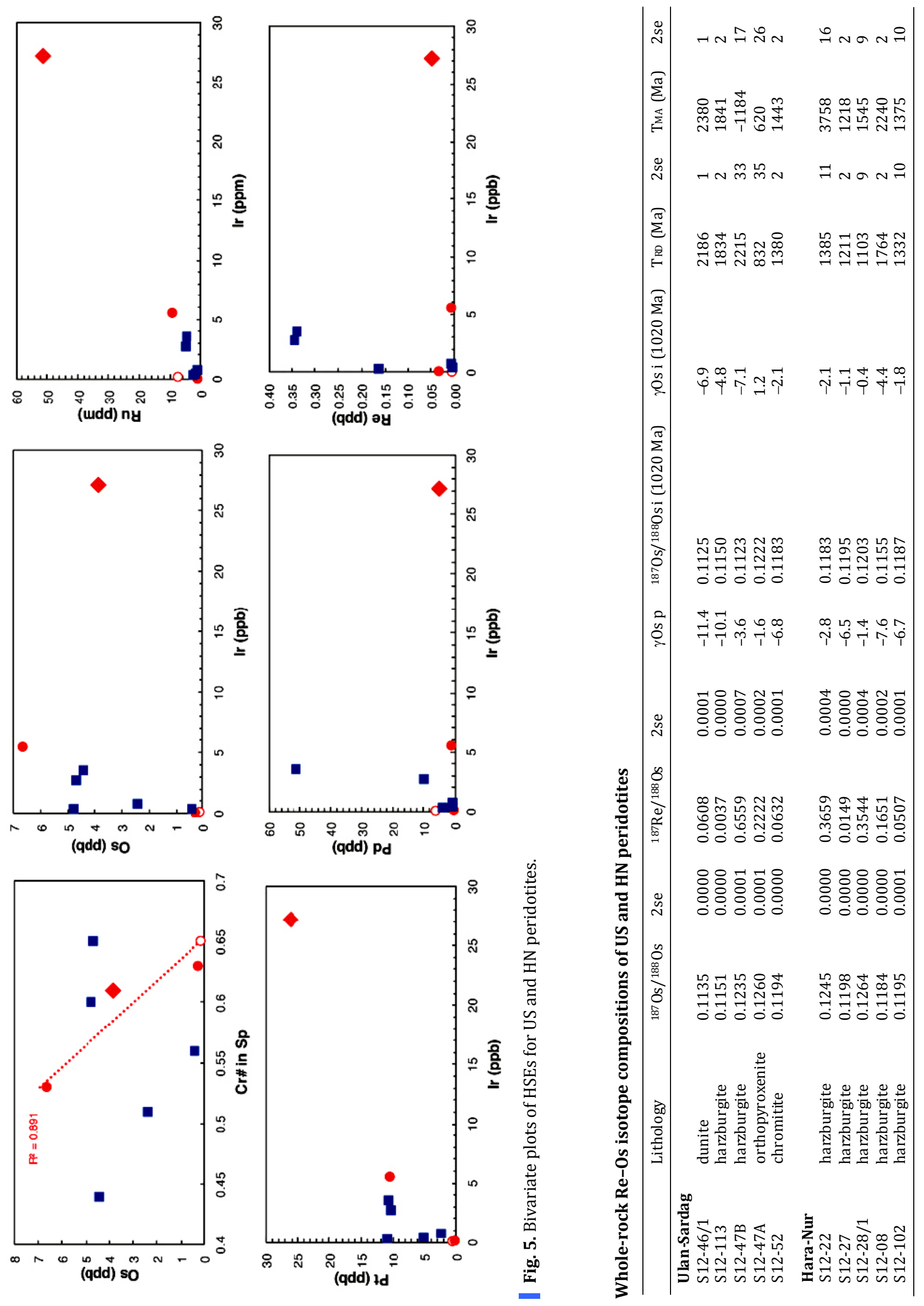


record major tectonic events prior to and associated with closure of paleo-Asian ocean at the southern margin of the Siberian craton since the late Mesoproterozoic time. The pristine residual signatures, along with the ancient Os model ages older than the Dunzhugur ophiolites cannot be ascribed to recycled (subducted) ancient crustal materials in the lithospheric mantle. Similar crustal event age peaks occur in the South China block/Laurentia, suggesting a connection with the southern Siberian craton before the opening of the Paleo-Asian ocean. Thus, remnant lithospheric fragments stranded by rifting of the ancient continental regions are inferred to occur in the Neoproterozoic Dunzhugur ophiolites as observed in modern ocean basins [O'Reilly et al., 2009].

Conclusion. Mineral chemistry and whole-rock trace and PGE data indicate that formation of the HaraNur and Ulan-Sardag peridotites cannot be explained by a single stage melting event but at least two-stages of melting and re-enrichment processes are needed to explain their geochemical characteristics. Their traceelement patterns are similar to residual peridotites melted in a SSZ environment indicating these depleted harzburgites and dunites are the product of melting and related re-enrichment took place in SSZ. The pristine residual signatures, along with the ancient Os model ages older than the Dunzhugur ophiolites cannot be ascribed to recycled (subducted) ancient crustal materials in the lithospheric mantle. Similar crustal event age peaks occur in the South China block/Laurentia, suggesting a connection with the southern Siberian craton before the opening of the Paleo-Asian ocean. Thus, remnant lithospheric fragments stranded by rifting of the ancient continental regions are inferred to occur in the Neoproterozoic Dunzhugur ophiolites as observed in modern ocean basins.

\section{REFERENCES}

Dick H.J.B., Bullen T., 1984. Chromian spinel as a petrogenetic indicator in abyssal and alpine-type peridotites and spatially associated lavas. Contributions to Mineralogy and Petrology 86 (1), 54-76. https://doi.org/10.1007/ BF00373711.

Dobretsov N.L., Konnikov E.G., Medvedev V.N., Sklyarov E.V., 1985. Ophiolites and olistostromes of the Eastern Sayan. In: N.L. Dobretsov (Ed.), Riphean - Early Paleozoic ophiolites of Northern Eurasia. Nauka, Novosibirsk, p. 34-58 (in Russian).

Khain E.V., Bibikova E.V., Kröner A., Zhuravlev D.Z., Sklyarov E.V., Fedotova A.A., Kravchenko-Berezhnoy I.R., 2002. The most ancient ophiolite of the Central Asian fold belt: $\mathrm{U}-\mathrm{Pb}$ and $\mathrm{Pb}-\mathrm{Pb}$ zircon ages for the Dunzhugur complex, Eastern Sayan, Siberia, and geodynamic implications. Earth and Planetary Science Letters 199 (3-4), 311-325. https://doi.org/10.1016/S0012-821X(02)00587-3.

Kovach V.P., Rytsk E.Yu., Salnikova E.B., Yakovleva S.Z., Fedoseenko A.M., Skopintsev V.G., Lykhin D.A., 2012. New U-Pb (TIMS) geochronological data on age of tonalities of the Sumsunur complex of the Gargan Glyba - to discussion on Palaeozoic organics in ancient sequences of the East Sayan. In: V Russian conference on isotope geochronology. Conference abstracts. Institute of Geology of Ore Deposits, Petrography, Mineralogy and Biochemistry, Russian Academy of Sciences, Moscow, p. 158-160 (in Russian).

Kuzmichev A.B., 2004. Tectonic History of the Tuva-Mongolian Massif: Early Baikalian, Late Baikalian and Early Caledonian stages. PROBEL-2000, Moscow, 192 p. (in Russian).

Kuzmichev A.B., Bibikova E.V., Zhuravlev D.Z., 2001. Neoproterozoic ( $800 \mathrm{Ma}$ ) orogeny in the Tuva-Mongolia massif (Siberia): island arc-continent collision at the northeast Rodinia margin. Precambrian Research 110 (1-4), 109-126. https://doi.org/10.1016/S0301-9268(01)00183-8.

Kuzmichev A.B., Larionov A.N., 2013. Neoproterozoic island arcs in East Sayan: duration of magmatism (from U-Pb zircon dating of volcanic clastics). Russian Geology and Geophysics 54 (1), 34-43. https://doi.org/10.1016/j.rgg. 2012.12.003.

McDonough W.F., Sun S.-S., 1995. The composition of the Earth. Chemical Geology 120 (3-4), 223-253. https://doi.org/ 10.1016/0009-2541(94)00140-4.

O'Reilly S.Y., Zhang M., Griffin W.L., Begg G., Hronsky J., 2009. Ultradeep continental roots and their oceanic remnants: A solution to the geochemical "mantle reservoir" problem? Lithos 112 (Supplement 2), 1043-1054. https://doi.org/ 10.1016/j.lithos.2009.04.028.

Parkinson I.J., Pearce J.A., 1998. Peridotites from the Izu-Bonin-Mariana forearc (ODP Leg 125): evidence for mantle melting and melt-mantle interaction in a supra-subduction zone setting. Journal of Petrology 39 (9), 1577-1618. https://doi.org/10.1093/petroj/39.9.1577.

Sklyarov E.V., Kovach V.P., Kotov A.B., Kuzmichev A.B., Lavrenchuk A.V., Perelyaev V.I., Shchipansky A.A., 2016. Boninites and ophiolites: problems of their relations and petrogenesis of boninites. Russian Geology and Geophysics 57 (1), 127-140. https://doi.org/10.1016/j.rgg.2016.01.009. 